\title{
Crown gall can spread between walnut trees in nurseries and reduce future yields
}

\begin{abstract}
by Lynn Epstein, Sukhwinder Kaur, James R. McKenna, Joseph A. Grant, William H. Olson and Wilbur O. Reil
\end{abstract}

While walnut trees on Juglans hindsii $x$ J. regia 'Paradox' rootstocks are highly susceptible to crown gall, it is unknown whether this bacterial disease is acquired in the nursery or the orchard. We selected two groups of gall-free trees in nurseries, those adjacent to trees with and without galls. Two years after being transplanted in the orchard, trees in the group adjacent to those with galls had significantly greater - more than four times more - crown gall incidence than those adjacent to trees without galls (14\% versus $3 \%$ ). In addition, trees in prolonged (17-day), bare-root, unrefrigerated storage before transplanting were associated with higher crown-gall incidence. We also found that crown gall can decrease walnut tree productivity. For every quarter of trunk circumference that was galled, there was a $12 \%$ decrease in cumulative nut yield over the first 4 years of production.

T he United States is the largest producer of walnuts in the world, with nearly all the walnut acreage concentrated in California. In California, walnuts (Juglans regia, the 'English' walnut) are commonly grafted onto 'Paradox' rootstocks, which have a J. regia male parent and a black walnut female parent, generally J. hindsii (Potter et al. 2001). While 'Paradox' is vigorous and performs well in a variety of conditions, this rootstock is extremely susceptible to crown gall disease (McKenna and Epstein 2003).

Young galls are somewhat soft and spongy, not hard, and lack annual growth rings. Although large, gnarled

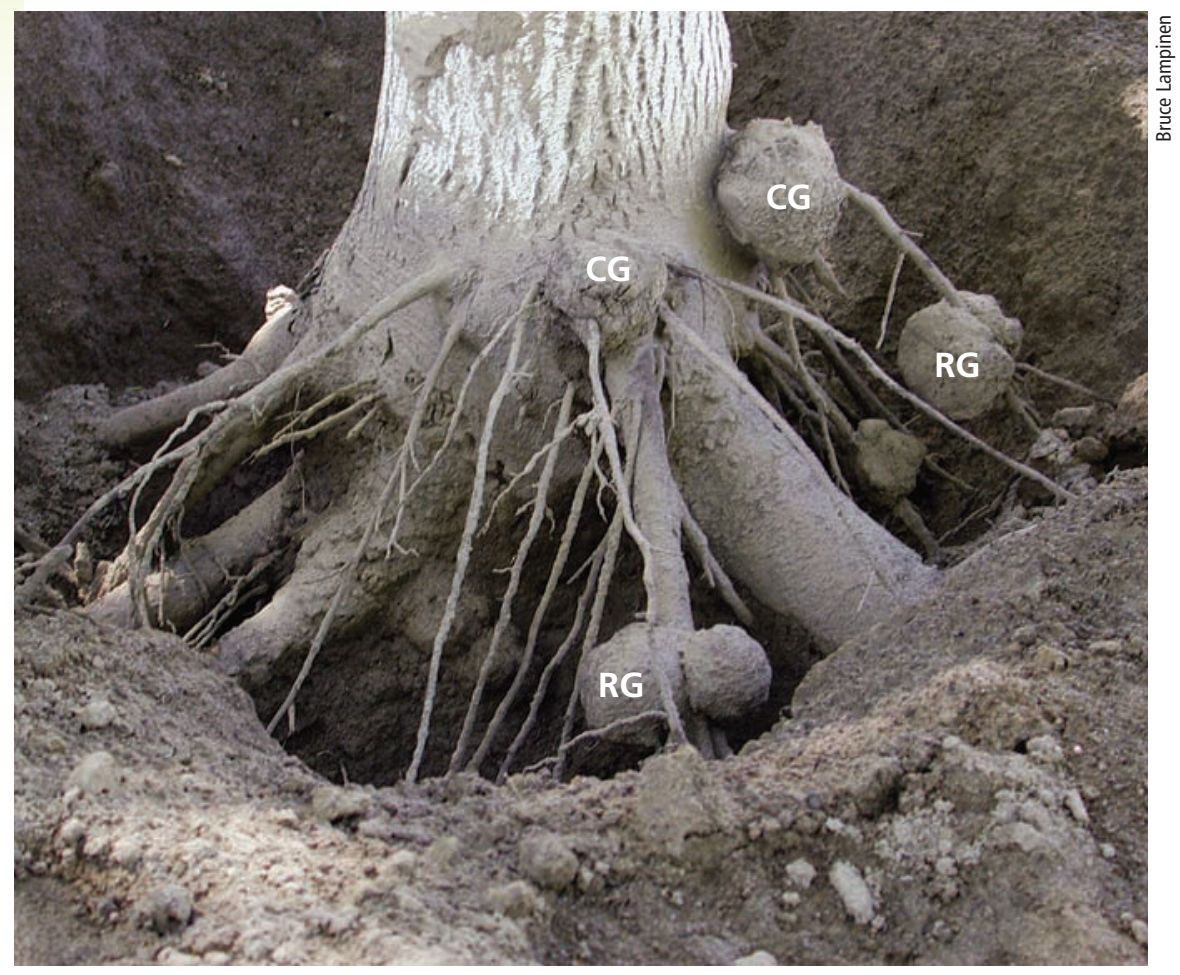

Crown galls (CG) and root galls (RG) are caused by Agrobacterium spp. Root galls generally have little impact, but crown galls may affect walnut tree growth and yield.

galls sometimes are visible at ground level, most galls are belowground on the crown (the juncture between the main roots and the trunk), or scattered along the roots. In contrast to galls on the crown, galls on the roots are generally smaller, and appear to have little impact on most trees (see photo).

Crown gall on walnuts is caused by two species of bacteria: Agrobacterium tumefaciens and $A$. rhizogenes (Young et al. 2001). A. tumefaciens is also known as A. tumefaciens biovar $1, A$. radiobacter and Rhizobium radiobacter, while $A$. rhizogenes is also known as $A$. tumefaciens biovar 2 and $R$. rhizogenes. In California, $A$. tumefaciens is a more common causal agent of crown gall in 'Paradox' than A. rhizogenes (Kaur and Epstein, unpublished), although the reverse may be true in Oregon or other locales (Moore and Canfield 1996).

Interactions between $A$. tumefaciens and various host plants have been investigated extensively on a molecular level. However, scientists know less about the impact of the disease and how the pathogen survives and spreads in nature. In 1912, Smith et al. stated that crown galls are "injurious to the plant in varying degrees, depending on the species, on the parts attacked, on the size and vigor of the individual, etc. They are most injurious to young and rapidly growing plants."

According to the literature, the impact of crown gall on fruit and nut trees varies. For example, Garrett (1987) reported that crown gall had no consistent impact on the growth of cherry trees, while others have reported that the disease causes stunting of pecans (Bouzar et al. 1983) and peaches (Htay and Kerr 1974), and mortality of peaches and cherries (Kainski 1964). However, we are unaware of reports in which the effect of gall on yield has been quantified. This information is essential for developing cost-effective recommendations for the prevention and treatment of this disease.

Crown gall affects nut and fruit trees in both nurseries and orchards. Based on observations of stone fruit trees, Moore (1976) and Alconero (1980) suggested that some infections are 
"latent," occurring in the nursery, but only developing galls after transplantation. Using more modern technology of DNA sequencing, Pionnat et al. (1999) concluded that pathogenic A. tumefaciens was transmitted on asymptomatic rootstocks of roses, and that the transmitted pathogen then caused disease in some buyers' fields. However, it is not known whether the infections occurred in the nursery or after transplanting.

We present an experiment and an observational study in which pretransplant practices affected subsequent crown gall disease in walnut orchards. In addition, we quantified the negative impact of crown gall on the yield of young walnut trees.

\section{Nursery location and wounding}

Study design. In January 1999, we selected two groups of 200 trees without galls during tree harvest at a commercial walnut nursery in California. The first group of nongalled trees had grown next to trees without galls, and the second group had grown next to trees with galls. The selected trees were stored in sawdust beds.

Immediately before transplanting in March 1999, half of the trees in each group were wounded in the crown and taproot region by making 10 sweeping, horizontal cuts with a serrated blade; some of the cuts also extended onto the lateral roots. Trees were wounded because the pathogen infects wounded

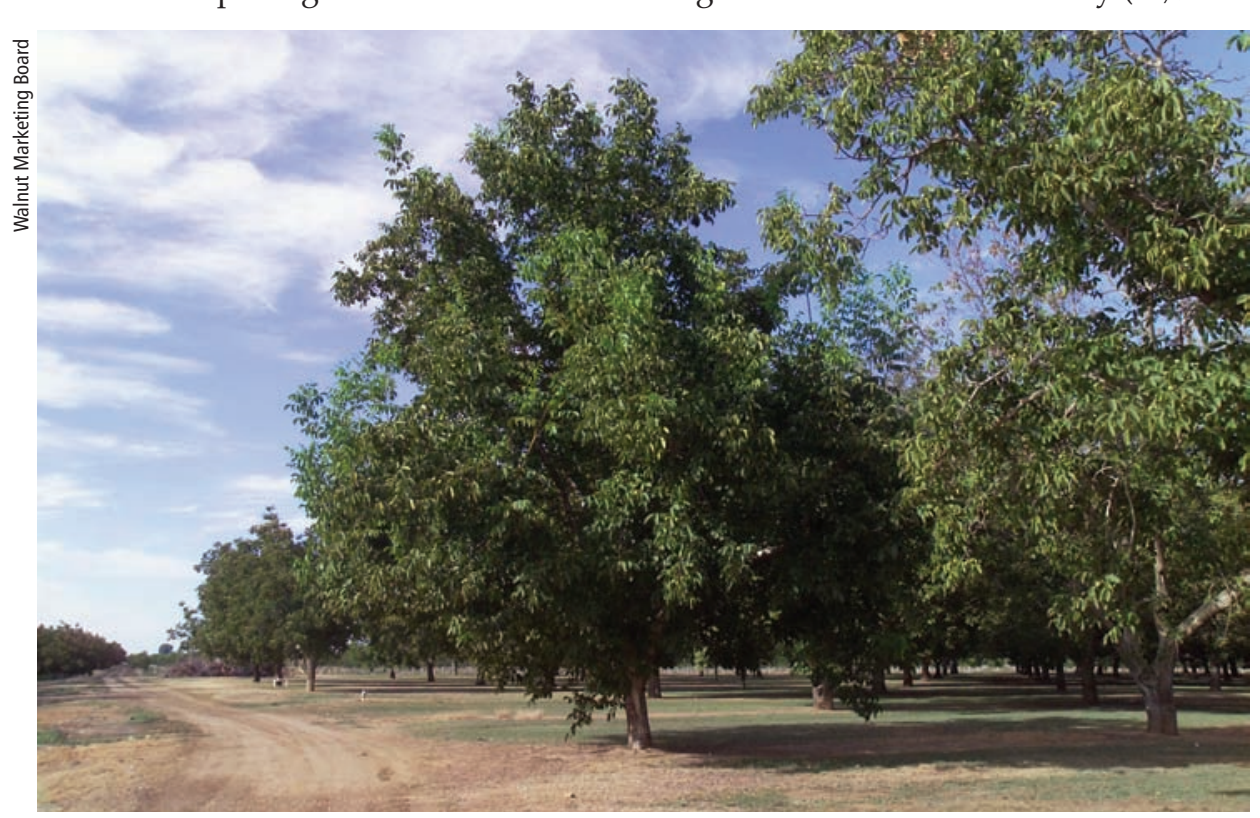

Most California walnut orchards are 'English' walnuts grafted onto 'Paradox' rootstock, which is highly susceptible to crown gall disease.

TABLE 1. Effect of location of 'Paradox' walnut seedlings in the nursery on subsequent development of crown gall in an orchard*

\begin{tabular}{|c|c|c|c|c|}
\hline $\begin{array}{l}\text { Next to a tree with a } \\
\text { gall in the nursery? }\end{array}$ & $\begin{array}{l}\text { Wounded before } \\
\text { transplanting? }\end{array}$ & $\begin{array}{l}\text { Trees with gall(s) } \\
\text { at the crownt }\end{array}$ & $\begin{array}{l}\text { Trees with gall(s) } \\
\text { on the rootf }\end{array}$ & $\begin{array}{c}\text { Trees } \\
\text { with galls§ }\end{array}$ \\
\hline & & . & $\% \cdots \cdots$ & $\ldots \ldots$ \\
\hline No & No & 2 & 16 & 17 \\
\hline No & Yes & 3 & 21 & 24 \\
\hline Yes & No & 13 & 21 & 26 \\
\hline Yes & Yes & 14 & 26 & 34 \\
\hline \multicolumn{5}{|c|}{ * Data analyzed by log linear models. } \\
\hline \multicolumn{5}{|c|}{$\begin{array}{l}\text { A model in which a gall at the crown was independent of both nursery position and wounding was rejected } \\
(P=0.005) \text {. Similarly, a model with gall dependent on wounding but not on nursery position was rejected }(P=0.0002) \text {. } \\
\text { However, a model with gall dependent on nursery position but not on wounding was not rejected }(P=0.88) \text {. }\end{array}$} \\
\hline \multicolumn{5}{|c|}{ ‡ No significant $(P>0.05)$ effects within this column. } \\
\hline \multicolumn{5}{|c|}{$\begin{array}{l}\text { § A model in which a gall was independent of both nursery position and wounding was barely rejected }(P=0.0495) \text {. } \\
\text { A model with gall dependent on nursery position but not on wounding was not rejected }(P=0.22) \text {. Similarly, a model } \\
\text { with gall dependent on wounding but not on nursery position was not rejected }(P=0.088) \text {. }\end{array}$} \\
\hline
\end{tabular}

\section{The pathogen can be acquired in the nursery, but a visible gall is not produced until after transplantation.}

cells, and our (largely incorrect) expectation was that wounded trees would have more disease than unwounded trees. Trees were transplanted into a field with no history of crown gall at the UC Davis Armstrong Farm. The trees were planted in a randomized block design with one replicate of each of the four treatments in 100 blocks. In November 2000, the trees were dug up, the roots were washed and the incidence of crown gall was recorded.

Nursery location. The transplanted 'Paradox' trees that had been next to trees with galls were significantly more likely to have galls at the crown than transplanted trees that had been next to gall-free trees in the nursery $(14 \%$ versus 3\%; table 1). The location history of a tree in the nursery did not have a significant effect on the incidence of galls on the roots, but did have a significant effect at $P<0.05$ on the incidence of galls overall. We found that the location history of the tree in the nursery can have a significant effect on the incidence of galls in an orchard, demonstrating that the pathogen can be acquired in the nursery, but a visible gall is not produced until after transplantation.

Wounding. The wounding treatment had no effect on the incidence of galls on the crown, but did have a slight effect on the incidence of galls overall because of a slightly higher incidence of galls on wounded than unwounded roots. McKenna and Epstein (2003) demonstrated that galls are associated with wounds that penetrate into the cambium or perhaps the phloem. In the crown, the cambium is the thin layer between the bark and the hardwood, and the phloem is a thin layer on the inside of the bark.

In our experience, wounds incurred during the normal course of harvesting and transplanting trees from commercial nurseries are rarely sufficiently deep to induce a gall, particularly in the crown region. To date, we have had four trials in which root-pruned transplants from a nursery were planted and dug again after 2 years (tables 1 and 2) (McKenna and Epstein 2003; Kaur and Epstein, unpublished). Galls were rarely present in locations with rootpruned transplants, even though the 
TABLE 2. Effect of pretransplant handling on subsequent crown gall incidence on 'Paradox' walnut rootstocks planted in three locations

\begin{tabular}{|c|c|c|c|c|c|}
\hline \multirow[b]{2}{*}{ Trial type } & \multirow[b]{2}{*}{ County } & \multirow[b]{2}{*}{ Gall location } & \multicolumn{3}{|c|}{ Initial nursery-storage group* } \\
\hline & & & A & B & C \\
\hline & & & \multicolumn{3}{|c|}{$\ldots \ldots$ trees with gall, $\%$. . . } \\
\hline Screening $†$ & Fresno & Crown or roots & 8 & 9 & 49 \\
\hline Screening $t$ & Fresno & Crown & 0 & 3 & 21 \\
\hline Orchard trialł & Yolo & Crown & 5 & 6 & 12 \\
\hline Orchard trialł & San Joaquin & Crown & 10 & 8 & 21 \\
\hline
\end{tabular}

* In winter 1997-1998, 0.24\%, 2.4\% and 1.1\% of trees were galled in nursery sites A, B and C, respectively. Nongalled trees from sites $A, B$ and $C$ were stored nonrefrigerated and bare-root for 3,6 and 17 days, respectively, on pallets before "healing in." For each trial, trees were planted in 1998 in a completely randomized block design with each replicate containing one or, less frequently, two trees from each initial nursery-storage group.

† Trees were dug, washed and rated for gall in February 2000. Pairwise comparisons using 2 and $P=0.05$ adjusted by the Bonferroni method to $P=0.016$ indicate that trees from the initial nursery-storage group $C$ had significantly $(P=0.0001)$ more gall on either the crowns and/or roots than trees from other groups, and that gall incidence in trees originating from groups $A$ and $B$ was not significantly different from each other $(P=0.6$ and $P=0.05$ for either the crown or roots, and crown only, respectively).

₹ Galls protruding above the soil were evaluated in fall 2002. Analysis by log-linear models indicated that nursery-storage group $(P=0.0001)$ and location of orchard trial $(P=0.001)$ significantly affected post-transplantation incidence of crown gall; no interaction terms are required in the model $(P=0.71)$. Pairwise comparisons of gall on trees originating from different nursery-storage groups, using $P=0.05$ adjusted by the Bonferroni method to $P=0.016$, indicated that trees originating in nursery-storage group $C$ had significantly $(P \leq 0.0002)$ greater gall incidence than trees from the other two groups. Also, trees originating from groups $A$ and $B$ did not $\operatorname{differ}(P=0.56)$.

biological control agent K84 (A. rhizogenes) was never used. In contrast, galls frequently formed at natural wounds such as sites where roots emerged, and they occasionally formed where suckers emerged.

\section{Storage impacts on disease}

Study design. In September 1996, three nursery sites (A, B and C) in Stanislaus County were fumigated with 425 pounds per acre of methyl bromide and chloropicrin $(75: 25)$ to kill pests, pathogens and weeds. In November 1996, each site was planted with seeds from a variety of 'Paradox' source trees, and the parentage mix was the same at all three sites. In 1998, 3,219 to 3,973 trees per site from sites A, B and C were dug on Feb. 23, Jan. 21 and Jan. 10, respectively. After digging, trees were washed and inspected for gall, and those with galls were discarded, as is standard nursery practice. Nongalled trees from sites A, B and C were stored bare-root in open-air conditions on pallets in unrefrigerated barns for 3, 6 and 17 days, respectively. These temporary, open-air storage times varied primarily due to El Niño rains, which delayed transfer to "healing-in" beds. During storage, the tree roots were wetted with a hose three times per day.

After storage, trees from sites A, B and $C$ were placed in healing-in beds for 6, 35 and 35 days, respectively. To heal-in, trees were buried upright in trenches of sandy soil that had been fumigated with methyl bromide and chloropicrin. Next, trees were washed free of soil and placed in a single commercial cold-storage facility for 8, 14 and 90 days, respectively.

After storage, the trees were planted in Yolo, San Joaquin and Fresno county sites. The Yolo and San Joaquin county trials were planted in portions of commercial orchard sites that had a completely randomized block design with four blocks, with various seed sources as the treatment. Each treatment contained seedlings produced from the nuts of a single tree. There were either three trees per replicate with one tree from each initial nursery-storage group, or six trees per replicate with two trees from each initial nurserystorage group. For each seed source, nursery storage was randomized in the post-transplantation trial.

Before planting, the Yolo County orchard site was fumigated with methyl bromide and chloropicrin, and transplants were treated with the biological control agent K84 (Galltrol, AgBioChem Inc., Orinda, Calif.). The San Joaquin County site, formerly planted with field and row crops, was not fumigated before planting and the transplants were treated with K84 before planting. In fall 2002, trees ( $n=119$ to 127 per initial nursery-storage group) with galls that protruded above the soil were counted in both orchards. The Fresno County site was a nematode screening trial in soil amended with two species of nematodes that infect walnuts, Pratylenchus vulnus and Meloidogyne incognita. The

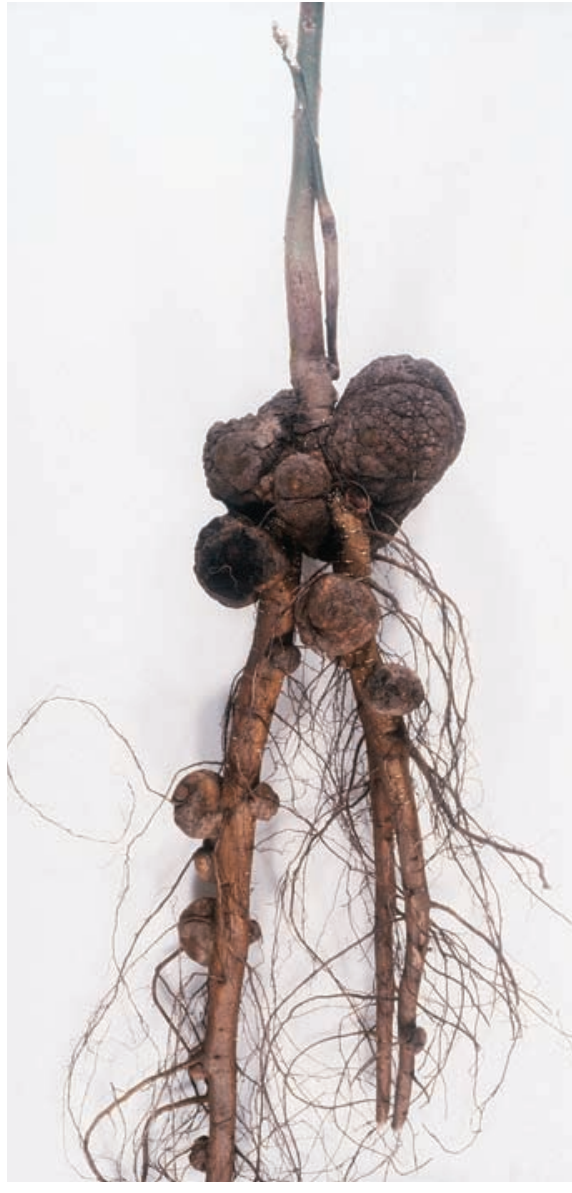

This budded walnut on 'Paradox' rootstock has both crown and root galls. Nurseries do not sell trees with visible galls, but may sell trees with roots that were in direct contact with galls and hence the pathogen.

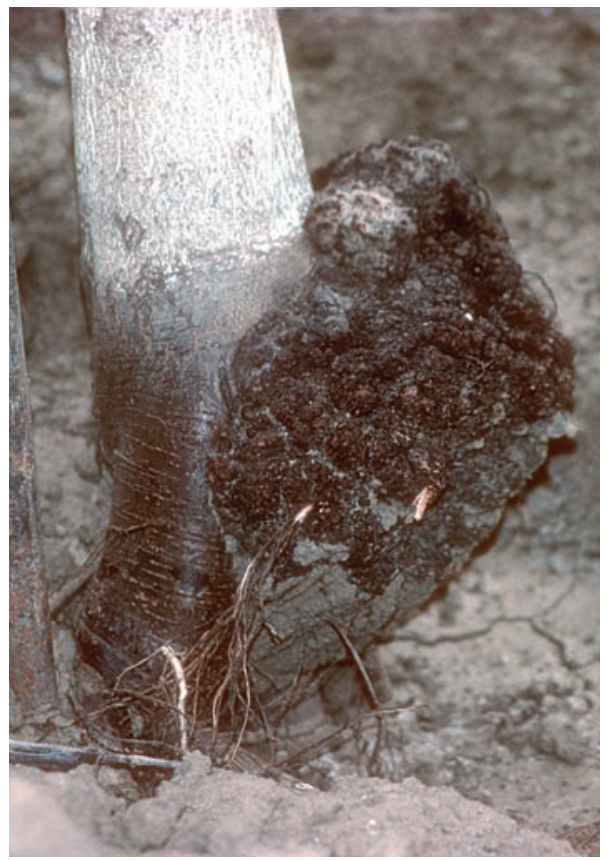

This 2-year-old tree on 'Paradox' rootstock had no gall and was treated with the biocontrol agent K84 at planting. Soil was removed from around the crown to show the gall. Circumstantial evidence indicates that the pathogen was acquired in the nursery. 


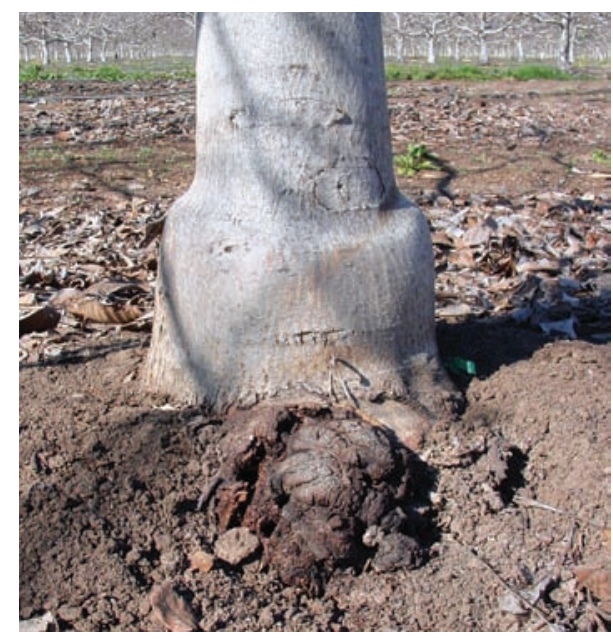

Some galls on the crown eventually break through the soil, but often are not visible in undisturbed soil until 3 or more years after infection. An application of the biocontrol agent K84 in the nursery and/or the orchard only prevents crown gall disease in certain situations, such as when the pathogen is exposed to and sensitive to K84.

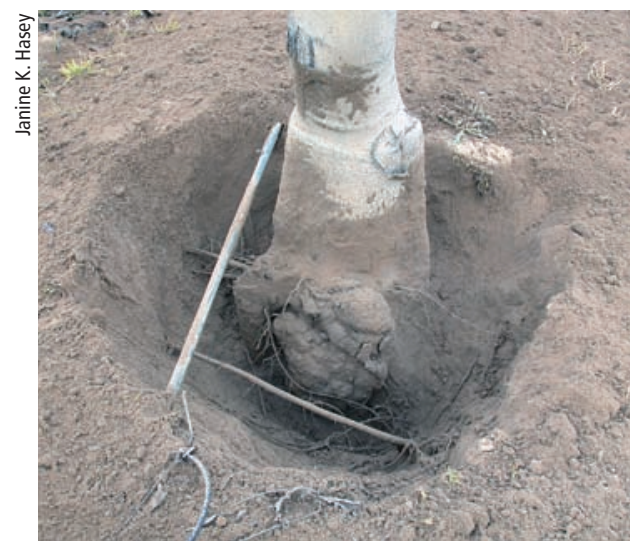

Severe crown gall in a young walnut orchard causes tree stunting and yield reductions. This gall was only visible after soil removal.

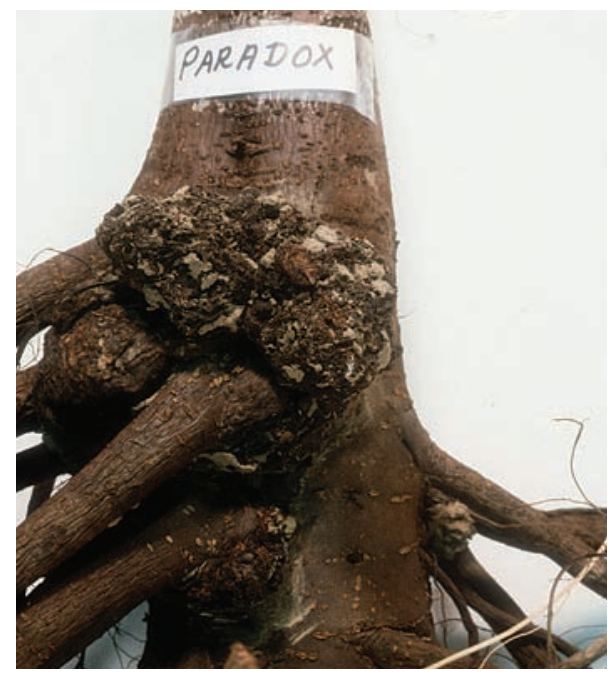

A 2-year-old walnut tree on 'Paradox' rootstock transplanted into soil infested with the pathogen Agrobacterium tumefaciens shows crown galls. Galls were primarily located at the sites of natural wounds such as root emergence, and were rarely observed on pruning wounds or cuts.

\section{For each quarter of crown circumference affected by gall, there was a $12 \%$ decrease in cumulative yield.}

soil was not fumigated and K84 was not used. In February 2000, trees ( $\mathrm{n}=154$ to 217 per initial nursery-storage group) were dug, washed and inspected for crown gall.

Open-air storage. When the 1-yearold trees were dug at the nurseries, gall incidence was relatively low: $0.24 \%$ in site A, $2.4 \%$ in site B and $1.1 \%$ in site C. Site $\mathrm{A}$ had been in pasture for the past 20 years, and sites $B$ and $C$ had been in a walnut-cover crop and peachcover crop rotation, respectively, for the past 10 years. Gall incidence was significantly greater for trees at nursery $\mathrm{B}$ than at nursery $\mathrm{C}(P=0.0001)$, and greater in trees at nursery $C$ than at nursery A $(P=0.0001$, pairwise comparisons using $X^{2}$ and $P=0.05$ adjusted by the Bonferroni method to $P=0.016$ ).

In all three post-transplantation orchard trials, trees that originated in nursery-storage group C had significantly more gall than trees from the other two groups (table 2). These trees had been stored in the open air for 14 and 11 days longer than those from sites $A$ and $B$, respectively. This suggests that prolonged open-air storage in warm, moist conditions was a critical factor associated with the increased galls in trees from site C. Rather than resulting from latent infections, the galls in our study with prolonged, unrefrigerated storage were more likely to have resulted

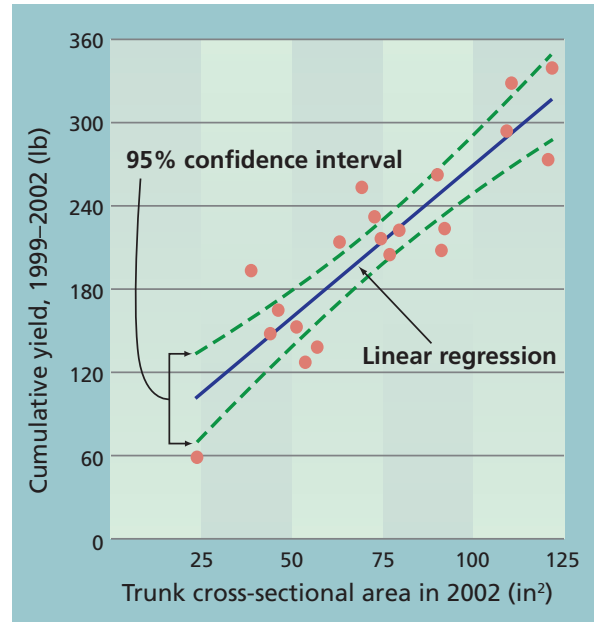

Fig. 1. Cumulative yield between 1999 and 2002, and trunk cross-sectional area in 2002 $\left(R^{2}=0.79, P=0.0001, y=2 x+52\right)$, for 20 randomly selected (in 1997, 1 year after transplanting) walnut trees on 'Paradox' rootstock, with varying severity of crown gall. from Agrobacterium cells that multiplied on the root surface and then were spread during wetting with a hose.

\section{Galls decrease growth, yield}

Study design. Two-year-old 'Paradox' seedlings (half-inch diameter) grafted with the J. regia selection 'UC76-80' were planted in a trial in Chico, Calif., in 1996. No galls were seen on the crown or roots, and the trees were washed and treated with the biological control agent K84. In 1997, about $1 \%$ of the 480 trees appeared to be stunted. After soil was removed from their crowns with water, crown galls were seen on many of the trees. The trees were rated on a scale of 0 to 3 for the extent of gall on the crown circumference: " 0 " for no gall, " 1 " for gall on a quarter or less of the crown, "2" for gall on between a quarter and half of the crown and " 3 " for gall on between half and three-quarters of the crown. Five trees in each category were randomly selected. The original soil excavated from each tree was returned to that tree. Tree circumference 4 inches below the graft union was recorded yearly, and dry nut yield per tree was recorded when bearing commenced in 1999. In 2002, soil was removed from the crown area with pressurized air, and the crown was assessed for how much of its circumference was affected by gall.

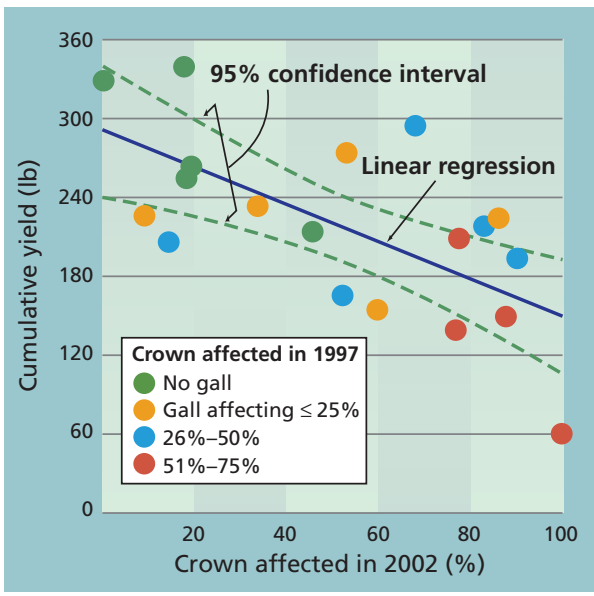

Fig. 2. Cumulative yield between 1999 and 2002 and percent crown circumference with a gall in $2002\left(R^{2}=0.44, P=0.0014\right.$, $y=-1.3 x+273)$, for 20 randomly selected (in 1997, 1 year after transplanting) walnut trees on 'Paradox' rootstock, with varying severity of crown gall. 
Growth and yield. Trunk circumference and cross-sectional area are proportional to tree size, and are an accepted way of comparing tree growth. Linear regression was used to examine how trunk cross-sectional area was affected by the extent of crown gall in 2002. Trees with more crown gall had decreased wood production in their trunks $\left(P=0.009, \mathrm{R}^{2}=0.32\right.$, y $=-0.49 x+101)$. Consequently, we conclude that crown galls result in less trunk wood.

In addition, the 2002 trunk cross-sectional area was significantly correlated with cumulative walnut yield for the first 4 years of production from 1999 to 2002 (fig. 1) $\left(P=0.0001, \mathrm{R}^{2}=0.79, \mathrm{y}=2 \mathrm{x}+52\right)$. Consequently, we conclude that trunk girth is a good predictor of nut yield and that trees with less girth will have a lower average yield.

Linear regression was used to examine how cumulative yield was affected by the extent of crown gall in 2002 (fig. 2) $\left(P=0.0014, \mathrm{R}^{2}=0.44, \mathrm{y}=-1.3 \mathrm{x}+273\right)$. We found that $44 \%$ of the variance in cumulative walnut yield from 1999 to 2002 could be attributed to the amount of gall circumscribing the crown in 2002. For each quarter of crown circumference affected by gall, there was a $12 \%$ decrease in cumulative yield.

The data also showed that the extent of initial gall and final gall were correlated $\left(P=0.0001, \mathrm{R}^{2}=0.57, \mathrm{y}=21 \mathrm{x}+22\right)$. That is, the amount of crown engulfed in gall 1 year after planting was a reasonable predictor of the amount that would be engulfed in gall 5 years later. In contrast to galls on the crown, those on the roots were poor predictors of yield (data not shown). Consequently, while we conclude that gall on the crowns of young walnut trees has a significant effect on cumulative yield, galls on the roots do not.

\section{Managing galls}

Extrapolating from these results, if walnut growers remove soil a year after planting and see crown galls in a high proportion of the trees, they can then predict the reduction in nut yield in the first 4 years of production. Nut yield

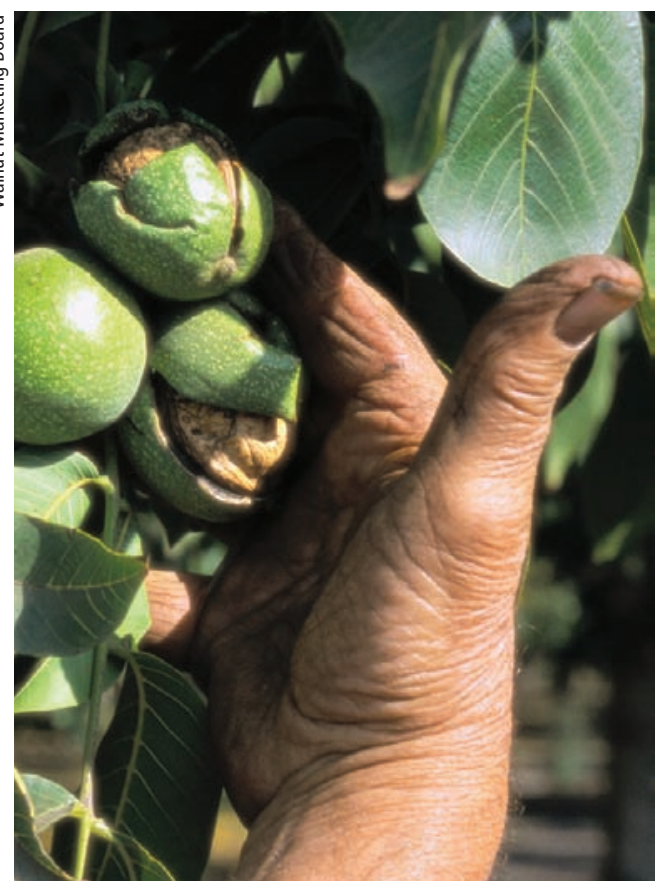

will be reduced by up to $17 \%$ if gall affects less than one-quarter of the crown, by $18 \%$ to $36 \%$ if gall affects between one-quarter and half of the crown, and by $36 \%$ to $54 \%$ if gall affects between half and three-quarters of the crown.

Consequently, 1- to 4-year-old trees with severe gall should be replaced. We generally recommend surgical removal of crown galls on less severely infected trees that are 1 to 4 years old. More detailed recommendations and methods are described in the UC IPM Management Guidelines for Crown Gall on Walnut (UC IPM Online 2007).

L. Epstein is Professor, and S. Kaur is Staff Research Associate, Department of Plant Pathology, UC Davis; J.R. McKenna was Staff Research Associate, Department of Pomology, UC Davis, and is currently with the USDA Forest Service at Purdue University; J.A. Grant is Farm Advisor, UC Cooperative Extension (UCCE), San Joaquin County; W.H. Olson is Farm Advisor Emeritus, UCCE Butte County; and W.O. Reil is Farm Advisor Emeritus, UCCE Yolo County. We thank Susan Bassein for statistical advice; Ronald Snyder, Nicholas Bertagna, Jed Walton and Sam Metcalf for experimental assistance with the Chico trial, and the staff at California State University at Chico for orchard maintenance; several California walnut nurseries for generous donations of trees; $R \& J$ Dondero Farms and Deseret Farms for hosting commercial orchard comparison trials of 'Paradox' sources; and Michael McKenry for access to his trial. The research was supported in part by the California Walnut Board and the California Department of Food and Agriculture's Fruit Tree, Nut Tree and Grapevine Industry Advisory Board.
4 The study found that walnut yields were reduced roughly in proportion to the extent of crown gall disease. Growers should replace young trees with severe crown gall ( 1 to 4 years old), and surgically remove galls from those that are less severely affected.

\section{References}

Alconero R. 1980. Crown gall of peaches from Maryland, South Carolina, and Tennessee and problems with biological control. Plant Dis 64:835-8.

Bouzar H, Moore LW, Schaad NW. 1983. Crown gall of Agrobacterium strains and potential for biological control in Georgia. Plant Dis 67:310-2.

Garrett CME. 1987. The effect of crown gall on growth of cherry trees. Plant Pathol 36:339-45.

Htay K, Kerr A. 1974. Biological control of crown gall: Seed and root inoculation. J Appl Bacteriol 37:525-30.

Kainski JM. 1964. Bacterial crown gall disease on plants in Kansas. Plant Dis Rep 48:664-8.

McKenna JR, Epstein L. 2003. Relative susceptibility of Juglans species and interspecific hybrids to Agrobacterium tumefaciens. HortScience 38:435-9.

Moore LW. 1976. Latent infections and seasonal variability of crown gall development in seedlings of three Prunus species. Phytopathol 66:1097-101.

Moore LW, Canfield M. 1996. Biology of Agrobacterium and management of crown gall disease. In: Hall R (ed.). Principles and Practice of Managing Soilborne Plant Pathogens. St. Paul, Minn.: APS Pr. p 153-91.

Pionnat S, Keller H, Héricher D, et al. 1999. Ti plasmids from Agrobacterium characterize rootstock clones that initiated a spread of crown gall disease in Mediterranean countries. Appl Environ Microbiol 65:4197-206.

Potter D, Gao F, Baggett S, et al. 2001. Defining the sources of Paradox: DNA sequence markers for North American walnut (Juglans L.) species and hybrids. Scientia Hort 94:157-70.

Smith EF, Brown NA, McCulloch L. 1912. The structure and development of crown gall: A plant cancer. USDA Bull No 255. Government Printing Office, Washington, DC.

UC IPM Online. 2007. Pest Management Guidelines - Walnut Crown Gall. UC Statewide Integrated Pest Management Program. http://ucipm. ucdavis.edu/PMG/r881100211.html (updated 12/07)

Young JM, Kuykendall LD, Martinez-Romero E, et al. 2001. A revision of Rhizobium Frank 1889 with an emended description of the genus, and the inclusion of all species of Agrobacterium Conn 1942 and Allorhizobium undicola de Lajudie et al. 1998 as new combinations: Rhizobium radiobacter, $R$. rhizogenes, $R$. rubi, $R$. undicola and $R$. vitis. Intl J System Evol Microbiol 51:89-103. 